\title{
SPECIES DIVERSITY AND COMPOSITION ANALYSIS IN DIFFERENT FOREST TYPES OF CORBETT TIGER RESERVE, UTTARAKHAND, INDIA
}

\author{
Zaara Kidwai ${ }^{1}$, Manoj Matwal ${ }^{2}$, Ujjwal Kumar ${ }^{3}$, Shivam Shrotriya ${ }^{3}$, Farhat Masood ${ }^{4}$, Zalmai \\ Moheb $^{5}$, Nasim Ahmad Ansari ${ }^{3} \&$ Krishnaveer Singh ${ }^{6}$
}
${ }^{1}$ Ranthambhore Tiger Conservation Foundation, Sawai Madhopur Rajasthan - 322001, India Corresponding author: zaarakidwai@gmail.com,+91-7597753156
${ }^{2}$ Harela Society, Pitthoragarh, Uttarakhand - 262501, India (manojmatwal@gmail.com)
${ }^{3}$ Wildlife Institute of India, P.O. Box 18, Chandrabani, Dehradun, Uttarakhand - 248001, India
(ujjwalsinha00@gmail.com, s.shivam2007@hotmail.com, nasim@wii.gov.in)
${ }^{4}$ Department of Biological Science, University of Chester - CH1 4BJ, United Kingdom (masood.farhat@gmail.com)
${ }^{5}$ Department of Environmental Conservation, University of Massachusetts, 160 Holdsworth Way, Amherst, MA 01003-9285, USA (zalmaimoheb@gmail.com)
${ }^{6}$ Department of Wildlife Sciences, Aligarh Muslim University, Aligarh-202001, India (singhkaushal91@gmail.com)

\begin{abstract}
Vegetation classification for any area involves analysis of trees, shrubs and ground cover. These strata are the primary features to characterize the vegetation. Species density and diversity depends on several topographic and climatic variations. Patterns of species density, richness and diversity of different vegetation types were analyzed in Bijrani, Serpdulli and Dhikala ranges of Corbett Tiger Reserve, Uttarakhand, India from 24th March to 4th April, 2008. The aim of the study was to determine the vegetation composition in all three forest types of Corbett Tiger Reserve along with estimating respective diversity and richness values of major plant species. A total of 50 circular plots of 10 $\mathrm{m}$ radius each were randomly laid down in Teak Plantation, Mixed Forest and Sal Forest respectively covering a total area of $15700 \mathrm{~m}^{2}$ in each habitat. Similarly, 50 circular plots of $5 \mathrm{~m}$ radius and 50 circular plots of $1 \mathrm{~m}$ radius were sampled from the same vantage points for estimating shrub and grass cover. Shannon Weiner index $\left(\mathrm{H}^{\prime}\right)$ and Margelef's index $\left(R_{1}\right)$ were used for calculating species diversity and species richness respectively. Important value index was calculated for the tree species to find out the dominant species in the sampled habitat types. The observed mean tree density $(350.32 \pm 2.12 / \mathrm{ha})$ in teak plantation was found to be highest followed by sal $(256.05 \pm 8.11 / \mathrm{ha})$ and mixed forest $(218.48 \pm 3.14 / \mathrm{ha})$. However, mean shrub density was recorded to be highest in mixed forest $(487 \pm 23.2 / \mathrm{ha})$. Regeneration rate of the trees could not be estimated due to managed forest fire performed during that time. It is recommended to conduct a long term study in the forest of Corbett Tiger Reserve to better understand the species diversity and effect of increased disturbance on it (if any) in that region.
\end{abstract}

Keywords: Density; dominance; importance value index; species richness; vegetation

\section{Özet}

Bir yere ait bitki örtüsü analizi, ağaç, çalı ve toprak seviyesindeki bitkileri içerir. Bu bitki tabakaları, bitki örtüsünü oluşturan birincil niteliklerdir. Tür yoğunluğu ve çeşitliliği muhtelif yeryüzü şekli ve iklim değişkenlerine bağlıdır. Bu çalışma kapsamında, Uttarakhand - Hindistan'da yer alan Corbett Kaplan Rezervi Bijrani, Serpdulli ve Dhikala bölgelerindeki bitki örtüleri 24 Mart - 4 Nisan 2008 yılları arasında analiz edilmiştir. Bu çalışmanın amacı, bu üç orman tiplerindeki vejetasyon analizlerini yapmayı ve hâkim ağaç türlerine ait tür çeşitliliği ve zenginliğini ortaya koymayı hedeflemiştir. Bu maksatla Tik ağaçlandırma alanı, karışık orman ve Sal ormanı alanlarında toplamda 15700 $\mathrm{m}^{2}$ lik bir alana karşılık gelen $10 \mathrm{~m}$ çapında 50 dairesel deneme alanı alınmıştır. Benzer şekilde aynı alanlarda, çalı ve 
otsu türlere ait tabakaları incelemek maksadıyla sırasıyla $5 \mathrm{~m}$ çapında ve $1 \mathrm{~m}$ çapında 50'şer örnek alan alınmıştır. Tür çeşitliliği ve tür zenginliğini tespit etmek maksadıyla sırasıyla Shannon Weiner İndeksi ( $\left.H^{\prime}\right)$ ve Margelef İndeksi $\left(\mathrm{R}_{1}\right)$ kullanılmıştır. Orman tiplerindeki hâkim ağaç türünü belirlemek için önem değeri indeksi kullanılmıştır. En yüksek ortalama ağaç yoğunluğu Tik ağaçlandırma alanında (350.32 $\pm 2.12 /$ ha), daha sonra Sal $(256.05 \pm 8.11 /$ ha $)$ ve karışık orman alanında $(218.48 \pm 3.14 / \mathrm{ha})$ tespit edilmiştir. Bununla birlikte en yüksek çalı yoğunluğunun karış1k orman alanında $(487 \pm 23.2 /$ ha) olduğu bulunmuştur. Alanlarda kontrollü yangınlar düzenlendiği için gençleşme oranları belirlenememiştir. Corbett Kaplan Rezervinde uzun dönemli araştırmaların yapılması ile tür çeşitliliği ve muhtemel şiddetli orman zararlarının etkilerinin anlaşılması mümkün olabilecektir.

Anahtar kelimeler: Yoğunluk, hâkim tür, önem değer indeksi, tür zenginliği, bitki örtüsü.

\section{INTROUCTION}

Classification of vegetation for any area requires analysis of three important strata, viz trees, shrubs and ground cover. These strata are the primary features that are noticed by someone when striving to characterize the vegetation (De 2007). Woodland ecosystems including forests encompass over $37 \%$ of the total earth's terrestrial surface (Dawson 1993; De 2007).

Vegetation composition and diversity have robust roles that control the ecosystem functioning in areas of biomass production and cycling of nutrients (Gower et al. 1992; Kidwai 2013). There is a strong correlation which exists between structural diversity of a region and its species diversity (Sahu et al. 2008; Kidwai 2013). A number of factors are responsible for resulting diversity of plants in a region. Species diversity of both plants and animals depends on several topographic and climatic variations. It is usually perceived that areas in the middle latitudes have high species diversity, particularly in the tropics because of the amiable climatic, edaphic and other factors prevailing inside them (De 2007). Corbett Tiger Reserve (CTR) is among the best conserved places for flora and fauna in the Himalayan region. This reserve has the attractive feature of being the pioneer wildlife conservation center in India (Dhakate et al. 2008; Kidwai et al. 2013).

The aim of this study was evaluating structure, composition and diversity of vegetation in the forests of Corbett Tiger Reserve and determining the overall health of its various forest types.

\section{MATERIALS AND METHODS}

The CTR is located at the foothills of the Western Himalayas in the civil district of Nainital and Pauri Garhwal in Uttarakhand, India at Latitudes $29^{\circ} 2529^{\circ} 40^{\prime} \mathrm{N}$ and Longitude $78^{\circ} 5-79^{\circ} 5^{\prime} \mathrm{E}$ (Fig. 1). In 1973-1974, CTR with Sonanadi Wildlife Sanctuary was designated as 'Tiger Reserve', under 'Project 'Tiger' of the Government of India which is now a leading protected area with a high density of tigers (Jhala et al. 2008; Kidwai et al. 2013). The area of the National Park is about $520.82 \mathrm{~km}^{2}$. The area of the Reserve further is $1288.32 \mathrm{~km}^{2}$ (with 301.18 $\mathrm{km}^{2}$ of Sonanadi Wildlife Sanctuary and the remaining $466.32 \mathrm{~km}^{2}$ as buffer area).

The vegetation of CTR is a mixture of unique forest types such as dry and moist deciduous forest, scrub savannah and alluvial grassland. Five major vegetation communities are found in the area (Champion \& Seth, 1986): (1) Sal (Shorea robusta) - dominated forest, (2) Sal Mixed Forest, (3) riverine forest, (4) mixed or miscellaneous forest, and (5) plantation. Grassland and open scrub are yet another two additional vegetation types found here. The most dominant and widely distributed species reported is Shorea robusta followed by Mallotus philippensis and Syzygium cumini. Plantations contribute to a significant part of the area with species such as Tectona grandis and Dalbergia sissoo. The park is refuge to rich and diverse fauna including 50 species of mammals, 575 species of birds, 33 species of reptiles, and 7 species of amphibians. The park has a high density of tigers Panthera tigris and a sizeable population of Asian elephants Elephas maximus (Badola et al. 2010).

Teak Plantation encompasses the area which has been vacated by villagers through relocation from park area. The Forest Management Authority planted mainly Teak (Tectona grandis), because it is fast growing plant species, climatic conditions are suitable for it, and it provides good habitat for animals. Some exotic varieties of plants, also, have been planted here for rapid recovery of the forest land such as Metroxylon sagu, Allanthes, and Eucalyptus. Some other species of plants like Mallotus phillipensis, Adina cordifolia, Diospyros melanoxylon and Shorea robusta were also found.

The Mixed Forests comprise a large proportion of the CTR. The forest is being exploited by local people for collection of fodder, fuel and other major and minor forest produces. Tendu 
(Diospyros melanoxylon) leaves are used for making 'bidis'. The Mixed Forests are distribution patchily in the CTR. The Mixed Forest possesses a variety of tree species such as Tendu (Diospyros melanoxylon), Haldu (Adina cardifolia), Teak (Tectona grandis), Rohini (Mallotus phillipensis), Bargad (Ficus bengalensis) and so on.

The Corbett Tiger Reserve is known for its Sal forest habitat. Sal (Shorea robusta) tree is tropical deciduous tree and provides good habitat for wild animals. Its viability of seeds is only 24-36 hrs. This character is very important from the
Seedlings $(<10.5 \mathrm{~cm}$ circumference and less than $30 \mathrm{~cm}$ height) and saplings $(>10.5 \mathrm{~cm}$ and $<31.4$ $\mathrm{cm}$ circumference and over $30 \mathrm{~cm}$ in height) were also enumerated on the circular plots of $5 \times 5$ meter. Girth at breast height (GBH) of the tree species in the plots were also measured along with calculating percent basal area on ground for comparing different habitats. Ocular estimation for tree, shrub and ground cover was also carried out.

Thus, a total of 150 sample plots were laid in the intensive study area to estimate the above

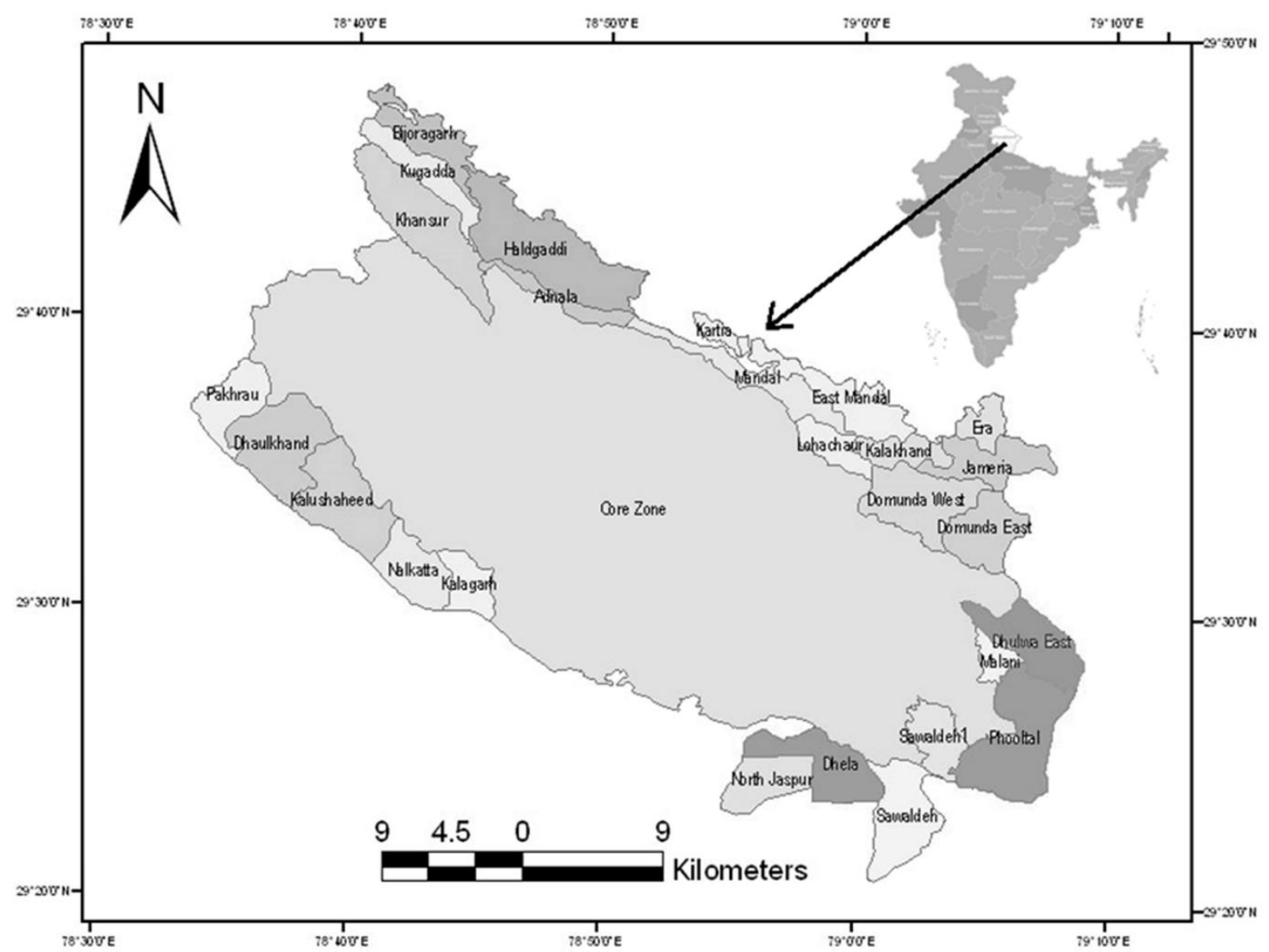

Fig. 1. Map showing details of the study area

management view point. The Sal forest is predominantly available from plains to slopes, where Pine forest meets. This forms very good eco-tones providing areas of the higher diversity. The study was carried out for 10 days as a part of Master's training program from 24th March to $4^{\text {th }}$ April, 2008. A total of 50 circular plots of 10 meter each were randomly laid down in Teak Plantation, Mixed Forest and Sal Forest respectively, covering total area of 15700 square meter in each habitat. Similarly, 50 circular plots of five meter and one meter each were sampled in the same vantage points for shrub and grass cover respectively (Saxena and Singh 1982). parameters for the evaluation of density (no. of trees per unit area), diversity and dominance of trees and shrubs along with evaluation of ground layer composition (Cummings and Smith, 2000) in the Corbett Tiger Reserve.

For calculating dominance of trees and shrubs, density of trees and shrub species was calculated in 'per hectare'. Dominance of a species was calculated by the value of the basal cover. $\mathrm{GBH}$ was calculated to determine the most dominant species in Corbett.

The importance value index (IVI) for tree species was estimated as the sum of relative density, 
relative frequency and relative dominance following Curtis (1959).

\section{RESULTS AND DISCUSSION}

a) Comparison of density of vegetation in three different types of forests sampled in CTR

Vegetation sampling of Teak Plantation was conducted near Garjia temple and around Dhela range. While, sampling for Mixed Forest was conducted in buffer area near Chorpani (Phooltal block). Sampling for Sal Forest was conducted in
Sarpduli range near Ringora. In areas of Teak Plantation, a total of 41 out of 50 plots were found to be burnt by Forest Department, which is a regular management activity in the beginning of summer. Following results were obtained:

Total tree density $( \pm \mathrm{SE})$ was calculated to be $350.32 \pm 2.12$ per hectare for Teak Plantation, 218.48 \pm 3.14 per hectare for Mixed Forest and $256.05 \pm 8.11$ per hectare for Sal Forest, respectively. Comparative density estimates of all three kinds of sampled forest is shown in Table 1.

Table 1: Total vegetation density ( \pm SE) of plants in three different forest types sampled in CTR

\begin{tabular}{|l|l|l|l|l|l|}
\hline \multirow{2}{*}{ Forest Type. } & \multicolumn{5}{|l|}{ Density \pm SE of vegetation stratum } \\
\cline { 2 - 6 } & Tree & Shrub & Herbs & Seedling & Sapling \\
\hline $\begin{array}{l}\text { Teak } \\
\text { Plantation }\end{array}$ & $350.32 \pm 2.12$ & $112 \pm 2.7$ & $8 \pm 3.2$ & $1.45 \pm 0.03$ & $2.03 \pm 1.3$ \\
\hline Mixed forest & $218.48 \pm 3.14$ & $487 \pm 23.2$ & $12 \pm 1.01$ & $3.07 \pm 0.98$ & $4.44 \pm 0.85$ \\
\hline Sal Forest & $256.05 \pm 8.11$ & $102 \pm 16.8$ & $9 \pm 2.01$ & $3.66 \pm 0.86$ & $3.98 \pm 0.72$ \\
\hline
\end{tabular}

The total density of shrubs was calculated to be $112 \pm 2.7$ per hectare for Teak Plantation, $487 \pm 23.2$ per hectare for Mixed Forest and $102 \pm 16.8$ per hectare for Sal Forest, respectively.

Species diversity and richness for each plot were calculated by using Shannon Weiner index $\left(\mathrm{H}^{\prime}\right)$ for species diversity and Margelef's index (R1) for species richness by using the formulae:

$\left(\mathrm{H}^{\prime}\right)=-\sum \mathrm{pi} \times \log \mathrm{pi}$ and $\left(\mathrm{R} 1^{\prime}\right)=\mathrm{s}-1 /$ In $\mathrm{N}$. Where, $\mathrm{pi}=$ proportion of $\mathrm{i}^{\text {th }}$ species in sample and $\mathrm{S}=$ number of species in sample and $\mathrm{N}=$ number of individuals. The analysis for richness and diversity estimation was done in SPECDIVERS; a DOS-based modified module of statistical ecology (Ludwing and Reynolds, 1988).

\section{b) Comparative Richness and Diversity estimates.}

Comparative diversity and richness estimates could be observed in Table $2 \mathrm{a}$ and $2 \mathrm{~b}$.

Diversity of tree species was calculated to be $1.34 \pm 0.15$ in Teak Plantation, $5.51 \pm 0.70$ in Mixed Forest and 3.15 \pm 0.24 in Sal Forest, respectively. 
Table 2a: Vegetation diversity $( \pm \mathrm{SE})$ of plants in three different forest types sampled in CTR

\begin{tabular}{|l|l|l|l|l|l|}
\hline \multirow{2}{*}{ Forest Types } & \multicolumn{5}{|l|}{ Diversity \pm SE in various vegetation stratum } \\
\cline { 2 - 6 } & Tree & Shrub & Herb & Seedling & Sapling \\
\hline Teak Plantation & $1.34 \pm 0.15$ & $1.77 \pm 0.42$ & $1.18 \pm 0.64$ & $0.45 \pm 0.04$ & $2.11 \pm 1.2$ \\
\hline Mixed Forest & $5.51 \pm 0.70$ & $5.65 \pm 0.99$ & $7.56 \pm 1.88$ & $6.83 \pm 1.27$ & $4.86 \pm 0.31$ \\
\hline Sal Forest & $3.15 \pm 0.24$ & $2.58 \pm 0.17$ & $1.26 \pm 0.79$ & $2.72 \pm 1.14$ & $3.03 \pm 1.41$ \\
\hline
\end{tabular}

Tree richness estimates were calculated to be $7.25 \pm 0.95$ in Teak Plantation, 14.23 \pm 2.27 in
Mixed Forest and 5.34 \pm 0.66 in Sal Forest, respectively.

Table 2b: Vegetation richness $( \pm \mathrm{SE})$ of plants in three different forest types sampled in CTR

\begin{tabular}{|l|l|l|l|l|l|}
\hline \multirow{2}{*}{ Forest Types } & \multicolumn{5}{|l|}{ Richness \pm SE in various vegetation stratum } \\
\cline { 2 - 6 } & Tree & Shrub & Herb & Seedling & Sapling \\
\hline Teak & & & & & \\
Plantation & $7.25 \pm 0.95$ & $4.24 \pm 1.22$ & $3.11 \pm 0.45$ & $2.10 \pm 0.35$ & $1.56 \pm 0.23$ \\
\hline Mixed Forest & $14.23 \pm 2.27$ & $8.97 \pm 1.54$ & $6.77 \pm 1.05$ & $4.14 \pm 1.13$ & $5.62 \pm 1.02$ \\
\hline Sal Forest & $5.34 \pm 0.66$ & $4.67 \pm 2.24$ & $4.28 \pm 1.11$ & $4.21 \pm 1.23$ & $3.20 \pm 0.24$ \\
\hline
\end{tabular}

c) Comparative IVI values and dominance estimates

In Teak Plantation, IVI of Tectona grandis was found to be the highest (282.97) with the lowest IVI of Terminalia sp. (4.24). In Mixed Forest is IVI of Diospyros melanoxylon was found to be the highest (118.35) with the lowest IVI of Tectona grandis (78.61). Whereas, in Sal Forest IVI of Shorea robusta was found to be the highest (282.97) with the lowest IVI of Eucalyptus spp. (4.64) as shown in Table 3.

Percent basal area was found to be maximum in Sal Forest (31.6\%) followed by Mixed Forest (19.9\%). The lowest percent basal area was recorded from Teak Plantation (17.7\%). 
Table 3: Comparative densities $( \pm \mathrm{SE})$ per hectare, Basal area and IVI of dominant tree species from the three habitat types surveyed in CTR.

$*$ NR $=$ Not Recorded

\begin{tabular}{|c|c|c|c|c|c|c|c|}
\hline \multirow{2}{*}{$\begin{array}{l}\text { S. } \\
\text { No. }\end{array}$} & \multirow[t]{2}{*}{ Tree Species } & \multicolumn{2}{|l|}{ Teak } & \multicolumn{2}{|l|}{ Mixed } & \multicolumn{2}{|l|}{ Sal } \\
\hline & & $\begin{array}{l}\text { Density } \pm S E \\
\text { (per hectare) }\end{array}$ & IVI & $\begin{array}{l}\text { Density } \pm S E \\
\text { (per hectare) }\end{array}$ & IVI & $\begin{array}{l}\text { Density } \pm S E \\
\text { (per hectare) }\end{array}$ & IVI \\
\hline 1. & Tectona grandis & $331.21 \pm 12.3$ & 282.97 & $62.42 \pm 9.34$ & 78.61 & NR* & $\mathrm{NR}^{*}$ \\
\hline 2. & Shorea robusta & $3.19 \pm 0.77$ & 12.55 & $13.38 \pm 2.77$ & 25.88 & $231.21 \pm 10.57$ & 287.27 \\
\hline 3. & Adina cordifolia & $1.27 \pm 0.05$ & 6.4 & $17.83 \pm 2.15$ & 75.85 & NR* & NR* \\
\hline 4. & Holoptelia integrifolia & $3.19 \pm 0.86$ & 11.36 & $\mathrm{NR}^{*}$ & $\mathrm{NR}^{*}$ & $\mathrm{NR}^{*}$ & $\mathrm{NR}^{*}$ \\
\hline 5. & Terminalia spp. & $0.64 \pm 0.01$ & 4.24 & $\mathrm{NR}^{*}$ & $\mathrm{NR}^{*}$ & $1.27 \pm 0.06$ & 4.89 \\
\hline 6. & Mellotus phillipensis & $9.55 \pm 0.97$ & 14.91 & $12.10 \pm 1.11$ & 28.25 & $19.75 \pm 2.54$ & 46.34 \\
\hline 7. & Diospyros melanoxylon & $1.27 \pm 0.03$ & 5.58 & $80.89 \pm 11.42$ & 118.35 & NR* & NR* \\
\hline 8. & Ficus bengalensis & $\mathrm{NR}^{*}$ & $\mathrm{NR}^{*}$ & $3.82 \pm 0.23$ & 36.23 & $\mathrm{NR}^{*}$ & $\mathrm{NR}^{*}$ \\
\hline 9. & Sysygium cumini & NR* & NR* & $2.55 \pm 0.35$ & 11.07 & $\mathrm{NR}^{*}$ & NR* \\
\hline 10. & Acacia catechu & $\mathrm{NR}^{*}$ & $\mathrm{NR}^{*}$ & $1.91 \pm 0.07$ & 4.91 & NR* & NR* \\
\hline 11. & Aegle marmelos & NR* & $\mathrm{NR}^{*}$ & $5.09 \pm 1.23$ & 18.25 & NR* & $\mathrm{NR}^{*}$ \\
\hline 12. & Bombax ceiba & NR* & NR* & $3.82 \pm 0.92$ & 15.96 & $\mathrm{NR}^{*}$ & NR* \\
\hline 13. & Schleichera oleosa & $\mathrm{NR}^{*}$ & NR* & $1.91 \pm 0.01$ & 7.42 & NR* & $\mathrm{NR}^{*}$ \\
\hline 14. & Anogeissus Latifolia & NR* & $\mathrm{NR}^{*}$ & $3.19 \pm 1.41$ & 13.18 & $\mathrm{NR}^{*}$ & $\mathrm{NR}^{*}$ \\
\hline 15. & Eucalyptus & $\mathrm{NR}^{*}$ & $\mathrm{NR}^{*}$ & $\mathrm{NR}^{*}$ & $\mathrm{NR}^{*}$ & $1.27 \pm 0.12$ & 4.64 \\
\hline 16. & Khoda & $\mathrm{NR}^{*}$ & $\mathrm{NR}^{*}$ & $\mathrm{NR}^{*}$ & $\mathrm{NR}^{*}$ & $2.54 \pm 0.05$ & 9.37 \\
\hline 17. & Dhaundi & $\mathrm{NR}^{*}$ & $\mathrm{NR}^{*}$ & $5.7 \pm 1.13$ & 21.53 & $\mathrm{NR}^{*}$ & $\mathrm{NR}^{*}$ \\
\hline 18. & Unidentified & $\mathrm{NR}^{*}$ & $\mathrm{NR}^{*}$ & $3.82 \pm 0.15$ & 8.51 & NR* & $\mathrm{NR}^{*}$ \\
\hline
\end{tabular}

d) Percent tree, shrub and ground cover in three types of sampled forests.

The tree cover in Teak Plantation and Mixed Forest was found to be in the low range of $0-35 \%$ (Fig. 2.1). However, Sal Forest had thick canopy cover with tree cover to be in medium range of 36-70 \% coverage. The shrub cover in Teak Plantation and Sal Forest was estimated to be in the low range of $0-15 \%$ (Fig. 2.2). Whereas, shrub cover in Mixed Forest was found to be in high coverage range of $>30 \%$ foliage cover. The common shrub species in all the three types of sampling areas was Clerodendrum viscosum. However, Mixed Forest had abundant Helicteres isora (Marorphali) (Density \pm SE $=243 \pm 5.43 / \mathrm{ha}$ ), and Lantana camara as well (Density \pm SE $=152 \pm 7.22 / \mathrm{ha}$ ). While Sal Forest had abundant Lantana camara only (Density \pm SE $=116 \pm 2.01 / \mathrm{ha})$. 


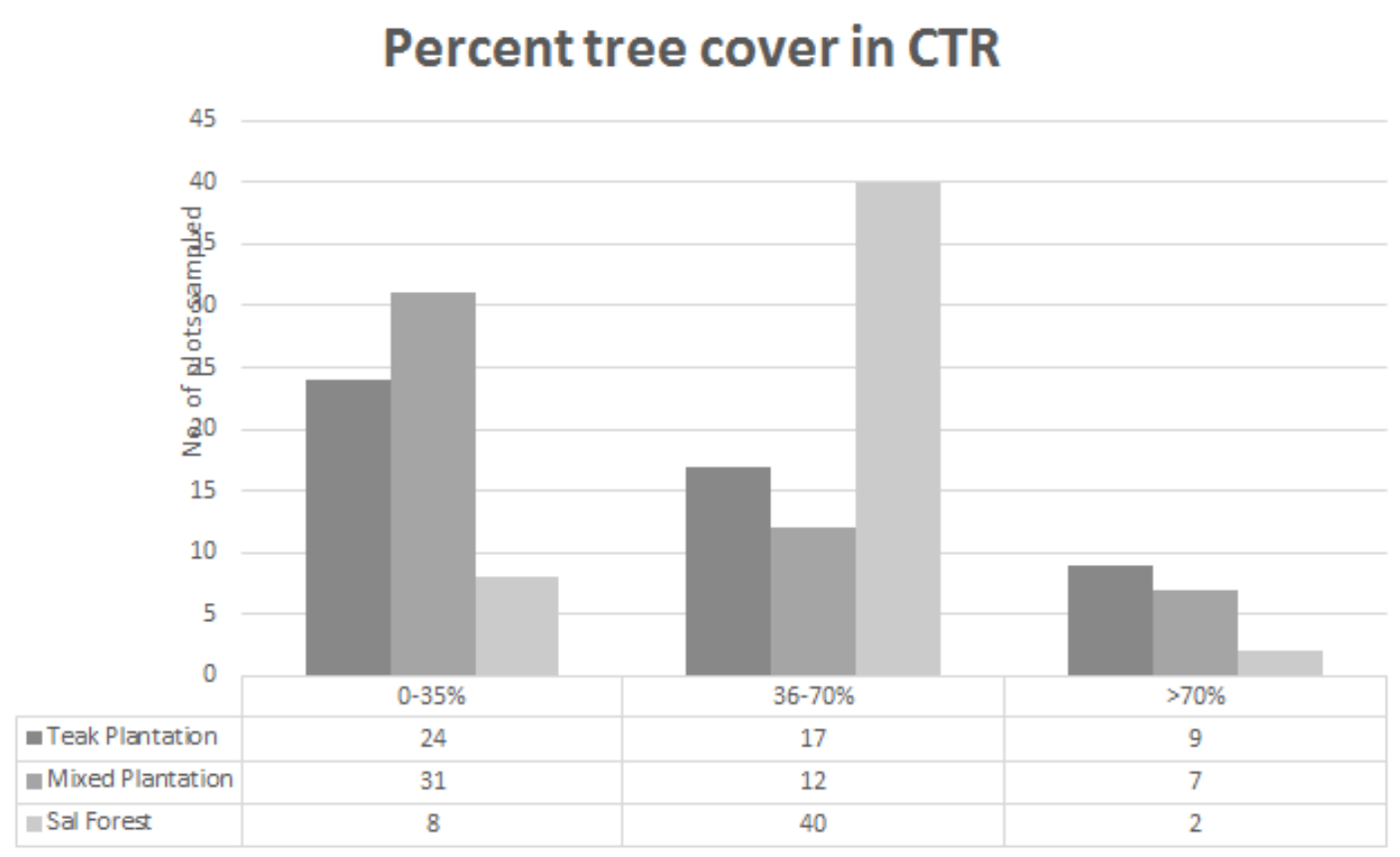

Fig. 2.1. Percent tree cover observed in three different kinds of forest types of CTR.

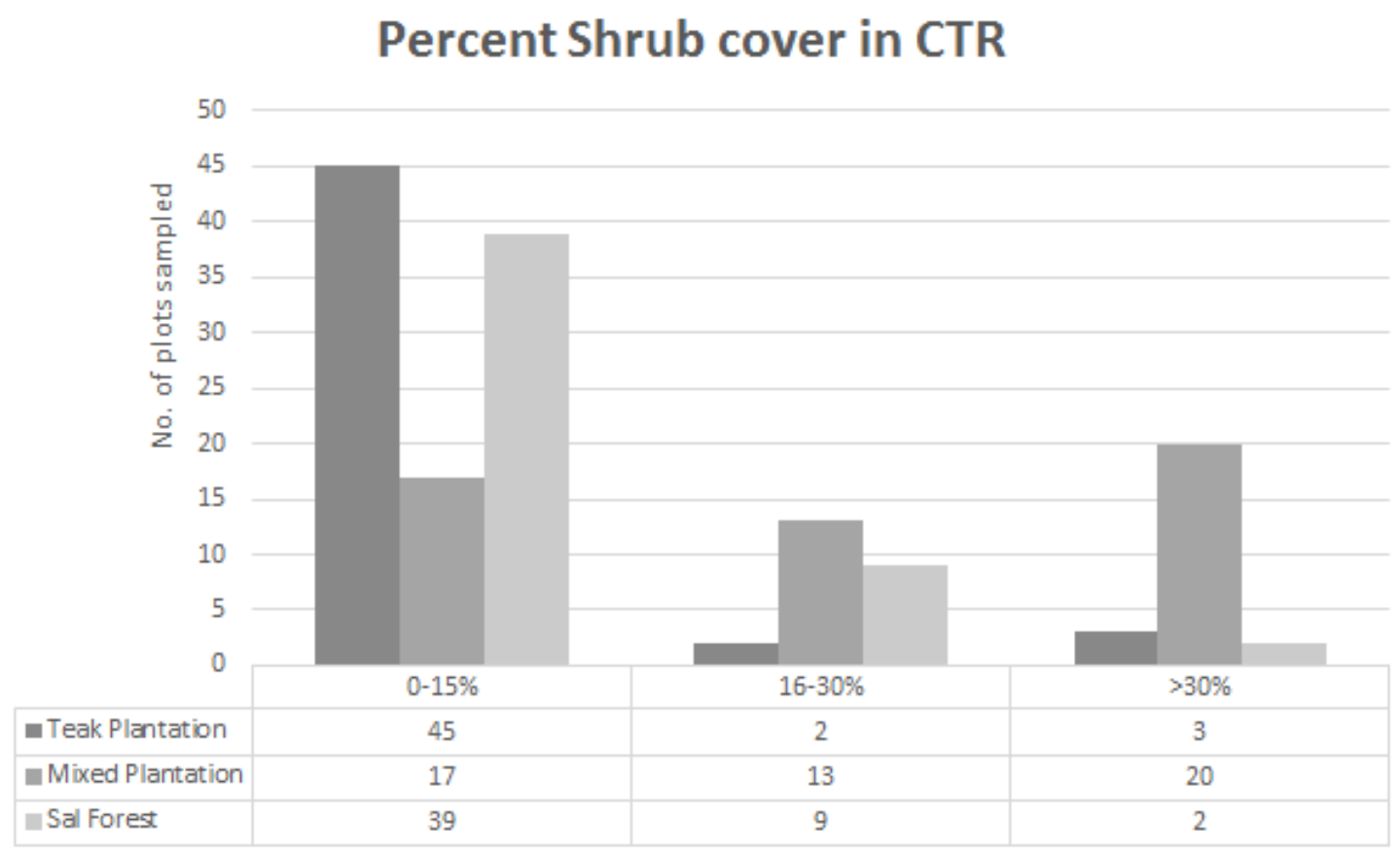

Fig. 2.2. Percent shrub cover observed in three different kinds of forest types of CTR

The grass cover in all the three kinds of forests surveyed was found to be in low cover range of $0-5 \%$ (Fig. 2.3). An interesting incident to note is that two encounters of tiger was experienced during our sampling procedures in Sal Forest. It demonstrates the healthy nature of Sal Forest for the survival of tigers and other faunal species. 


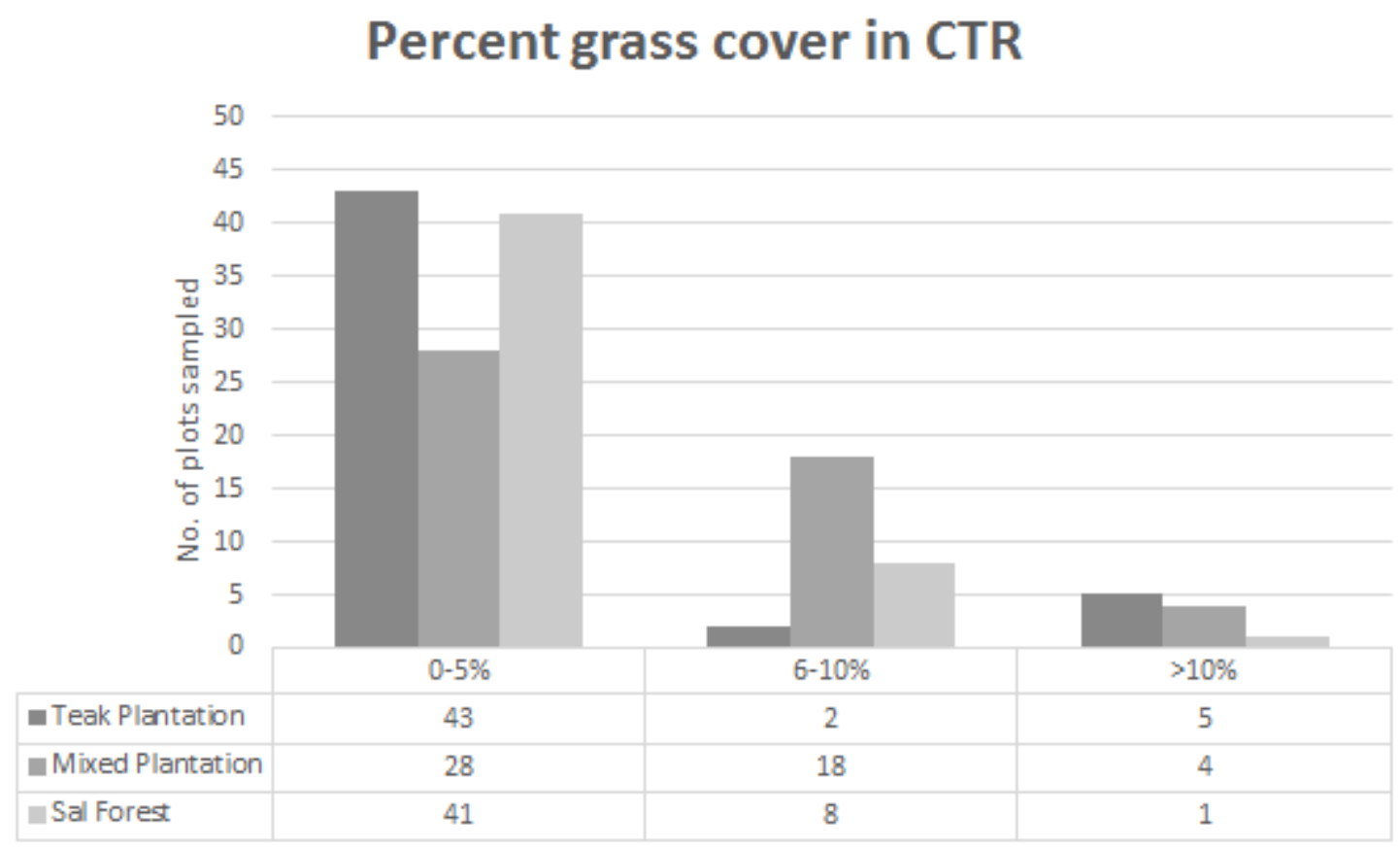

Fig. 2.3. Percent grass cover observed in three different kinds of forest types of CTR

When compared, Mixed Forest were found to be the most diverse and rich habitat among the other habitat types. In this habitat, 14 tree species were found with almost nonpatchy distribution. Tectona grandis, Adina cordifolia, Ficus spp., Mallotus phillipensis and Shorea robusta were most common trees to be found after Diospros melanoxylon. However, tree density was quite low as the area was not so dense. Tree cover was comparatively low whereas shrub cover and grass cover were high (Fig. 2.1 and 2.2). Lantana was the most abundant shrub found in Mixed Forest. This could be detrimental in the long run to the forest since it is considered as a troublesome weed in the area (Babu et al. 2009).

Species richness in an area depends on various climatic and ecological factors (Kidwai 2013). Richness of a species in an ecosystem depicts its level of stability. In low disturbed environments or biologically controlled systems, the diversity of a species will be higher.

The area of Teak Plantation was most uniform and low in diversity. These plantations have been developed by forest department for management purpose. Though the number of trees was very high, most of the plantation was 18-20 years old (as per the forest department records), so percent basal area was found to be the lowest. Clerodendron infortunatum, is very abundant and is one of the most common shrub of the habitat. Most of the area was burned and dried having no or very low grass cover.

Sal Forests were the oldest type of the forest having, sometimes, more than 3 meter GBH. Percent basal area was found to be highest among all the sampled forest types. Although tree density in Sal Forest patches were appreciable, but the area was not reported to have high richness or diversity. Old and healthy trees were making a dense canopy cover, but grass and shrub were quite low because of recent managed forest fire.

It was also not easy to estimate the regeneration rate inside the forest due to the same reason. It is therefore, extremely important to conduct a long term study in the area for understanding the regenerated rate of trees in CTR. A study on effect of anthropogenic pressures on the diversity of these vegetation compositions should also be carried out to know their deterioration rate (if any). 


\section{ACKNOWLEDGEMENT}

We would like to thank the Forest Department staff of Corbett Tiger Reserve for providing necessary permissions to work inside the forest. We would like to thank Dr. Orus Ilyas, Assistant Professor and other teachers at Department of Wildlife Sciences (DWS) in Aligarh Muslim
University without whose encouragement we could not have been able to prepare the manuscript. We would also like to thank our supervisor Dr. Satish Kumar, Reader, at DWS, for guiding us through the work.

\section{EXPANDED ABSTRACT}

Woodland ecosystems including forests encompass over $37 \%$ of the total earth's terrestrial surface. Vegetation composition and diversity have robust roles that control the ecosystem functioning in areas of biomass production and cycling of nutrients. A number of factors are responsible for resulting diversity of plants in a region. Species diversity of both plants and animals depends on several topographic and climatic variations. The aim of this study was evaluating structure, composition and diversity of vegetation in the forests of Corbett Tiger Reserve and determining the overall health of its various forest types. The study was carried out for 10 days as a part of Master's training program from 24th March to $4^{\text {th }}$ April, 2008. A total of 50 circular plots of 10 meter each were randomly laid down in Teak Plantation, Mixed Forest and Sal Forest respectively, covering total area of 15700 square meter in each habitat. Similarly, 50 circular plots of five meter and one meter each were sampled in the same vantage points for shrub and grass cover respectively. Seedlings $(<10.5 \mathrm{~cm}$ circumference and less than $30 \mathrm{~cm}$ height) and saplings ( $>10.5 \mathrm{~cm}$ and $<31.4 \mathrm{~cm}$ circumference and over $30 \mathrm{~cm}$ in height) were also enumerated on the circular plots of 5 by 5 meter. Girth at breast height $(\mathrm{GBH})$ of the tree species in the plots were also measured along with calculating percent basal area on ground for comparing different habitats. Ocular estimation for tree, shrub and ground cover was also carried out. A total of 150 sample plots were therefore, laid in the intensive study area to estimate the above parameters for the evaluation of density (no. of trees per unit area), diversity and dominance of trees and shrubs along with evaluation of ground layer composition in the Corbett Tiger Reserve. Shannon Weiner index (H') and Margelef's index (R1) was used for calculating species diversity and species richness respectively. Important value index was calculated for the tree species to find out the dominant species in the sampled habitat types. The observed mean tree density $(350.32 \pm 2.12 / \mathrm{ha})$ in Teak Plantation was found to be highest followed by sal $(256.05 \pm 8.11 /$ ha) and Mixed Forest $(218.48 \pm 3.14 /$ ha). However, mean shrub density was recorded to be highest in Mixed Forest (487 $\pm 23.2 / \mathrm{ha})$. It is extremely important to conduct a long-term study in the area for understanding the regeneration rate of trees in CTR. A study on effect of anthropogenic pressures on the diversity of these vegetation compositions should also be carried out to know their deterioration rate (if any) 


\section{References}

Badola, R., Hussain, S. A., Mishra, B. K., Konthoujam, B., Thapliyal, S., and Dhakate, P. M., (2010). An assessment of ecosystem services of Corbett Tiger Reserve, India. Environmentalist 30(4), 320-329.

Babu, S., Love, A., and Babu, C.R. (2009). Ecological Restoration of Lantana-Invaded Landscapes in Corbett Tiger Reserve, India. Ecological Restoration 27(4), 467-477

Champion, H.G. and Seth, S.K., (1968). A revised survey of the forest types of India. Manager of publications, Govt., of India Press, New Delhi. pp. 404.

Cummings, J. and Smith, D., (2000). The line-intercept method: A tool for introductory plant ecology laboratories, 22, 234-246.

Curtis, J.T., (1959). The vegetation of Wisconsin. In: An Ordination of Plant Communities, Wisconsin Press, Madison.

Dawson, T. E. (1993). Woodland water balances. Trends in Ecology and Evolution 8, 120-121.

De, A., (2007). Patterns of plant species diversity in the forest corridor of Rajaji-Corbett National Parks, Uttaranchal, India. Current Science 92(1), 90-93.

Dhakate, P. M., Patil, T. A., and Bhartari, R., (2008). Wetland Birds of Corbett Tiger Reserve Landscape. Proceedings of Taal 2007; The $12^{\text {th }}$ World Lake Conference: $1974-1982$

Gower, S.T., Vogt, K.A. and Grier, C.C., (1992). Carbon dynamics of rocky mountain Douglas - fir: Influence of water \& nutrient availability. Ecological Monographs, 62(1), 4365.

Jhala, Y.V., Gopal, R., and Qureshi, Q., (2008). Status of tigers, co-predators \& prey in India. National Tiger Conservation Authority, Government of India, New Delhi, \& the Wildlife Institute of India, Dehra Dun. TR 08/001, pp. 151.

Kidwai, Z., (2013). Vegetation structure \& composition in core area of Sariska National Park, Rajasthan. Indian Forester, 139 (7), 636644.

Kidwai, Z., Matwal, M., Kumar, U., Shrotriya, S., Masood, F., Moheb, Z., Ansari, N.A. and
Singh, K., (2013). Comparative study of bird community structure \& function in two different forest types of Corbett National Park, Uttarakhand, India. Asian Journal of Conservation Biology, 2(2), 157-163.

Ludwig, J. B and Reynolds, J. F., (1988). Statistical Ecology: A primer on methods \& computing. John Wiley \& Sons. New York.

Sahu, P.K., Sagar, R., and Singh, J.S., (2008). Tropical forest structure \& diversity in relation to altitude \& disturbance in a Biosphere reserve in Central India. Applied Vegetation Science, 11, 461-470.

Saxena, A.K. and Singh, J.S., (1982). A phytosociological analysis of forest communities of part of Kumaun Himalaya. Vegetation 50, 3-22.

Submitted: 16.05.2016

Accepted: 22.11.2016 